\title{
Fatalism and Poverty in Fishing Communities
}

\section{Maksud Hakim (D)}

Department of Economic Development, Yapti Jeneponto School of Economics, 92315 Jeneponto, South Sulawesi, Indonesia; maksudhakim118@gmail.com

\begin{tabular}{l|l}
\hline ARTICLE INFO \\
\hline $\begin{array}{l}\text { Publication Info: } \\
\text { Research Article }\end{array}$
\end{tabular}

How to cite:

Hakim, M. (2019). Fatalism and Poverty in Fishing Communities. 7(2), 150-158.

DOI : 10.33019/society.v7i2.118

Copyright $\odot$ 2019. Owned by Author(s), published by Society

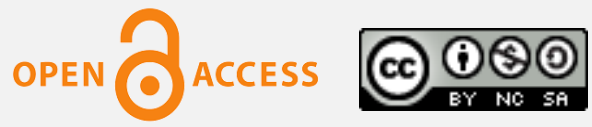

This is an open access article.

\section{License: Attribution- NonCommercial-ShareAlike (CC BY-NC-SA)}

Received: November 7, 2019; Accepted: December 15, 2019; Published: December 29, 2019;

\section{ABSTRACT}

This study aims to reveal the fatalistic work culture process as a cause of poverty for fishermen. As part of an urgent cultural aspect, Fatalism has been an inseparable part of their social life. Fatalism is an attitude that has been a stronghold for a long time and becomes a habit. In this case, the most important thing to express is the belief or trust of fishermen related to the coastal environment. This research took place on the southern coast of the Sulawesi Island, in Pandang-Pandang village, Arungkeke District, Jeneponto Regency, South Sulawesi Province, Indonesia. The informants were 5 poor fishermen from the Sawi (fishing boat crew) who were interviewed indepth and conducted observation of the surrounding environment. To strengthen research data, Literature studies, interview and observation results were also conducted. Data analysis used three path techniques including data reduction, categorization, and conclusion drawing. This research shows that; (1) The fatalistic attitude of the fishing community of Pandang-Pandang village manifested in the belief that life has been determined by God while humans only live and accept it, (2) Weak instrumental values of the fishing community in the form of not overly pursuing more values at work. Both of these are fatalistic attitudes. The conclusion of this research is the emergence of a fatalistic attitude in the fishing community is the result of their appreciation of God, Nature, Humans, and Life. This appreciation has been going on for a long time so that it is manifested in the form of an attitude of life than becoming an actor.

Copyright $@$ 2019. Owned by Author(s), published by Society. This is an open access article under CC-BY-NC-SA License. 


\section{Introduction}

Poverty among fishing communities in Indonesia has long been a concern for both the government and academics. The attention meant among others arises in the form of questions, why the fishing community remains poor on the one hand, while on the other hand, the country's economy experiences growth and improvement. This economic growth could theoretically reduce absolute poverty.

Some research on fishermen stated that this community belongs to the poor group (Suyanto, 2013; Mubyarto, 1984; Kusnadi, 2002, 2004; Masyhuri, 1999; Imron, 2001). Moreover, fishing communities have social groups, some groups are classified as very poor, and they are traditional fishermen and labor fishermen (Retni \& Santiasih, 1993).

In fishing communities, indications of poverty seem empirical. This can be seen from the physical facts in the form of very simple residential conditions, woven bamboo walls and thatched roofs, bamboo floors and sandy soil, limited ownership of household furniture, relatively low-income levels, daily consumption patterns, and including education levels of their children (Arifin, 2015). This indicator is also used in Malaysia to see whether fishermen are poor or not (Rasool et al., 2011).

On the southern coast of Sulawesi, the reality of poverty is also seen in a fishing community in Jeneponto Regency, South Sulawesi Province, Indonesia. The community is located on one of the long beaches and is occupied by several other fishing communities. One such community is the fishing community of Pandang-Pandang village, Arungkeke District.

In the fishing community, their livelihoods are only as fishermen and they do not have alternative jobs as fishermen in other regions in the same sub-district. The fishing community in this village uses various types of fishing gear by their abilities in the procurement of the equipment. Some of the tools that they commonly use are nets or lanra (gillnet), rinta (fishing line), and rengge (purse seine). The fishermen rely on these tools as the main source of income for their lives. The condition is also as in Palu (Central Sulawesi) and Sinjai (South Sulawesi) areas where local fishermen use traditional fishing gear (Anriani, 2018; Kamaruddin \& Halim, 2014). However, the works do not automatically improve their welfare in general. The fishing community lives is categorized as a backward, isolated, slum, and poor village.

Another social reality as an indicator of poverty in Sawi fishermen in Pandang-Pandang village is the levels of dependence on Punggawa (the financier), a very low-level education, and uncertainty income. The Sawi depend on the Punggawa to finance their work activities. Every time they want to go fishing, the Sawi always go to the Retainer earlier for routine and maintenance costs. Loan repayments are made after they have income earned after returning from fishing, and so on. Likewise, housewives in meeting their family consumption needs, they must take loans from the Retainer so that eventually they are in debt. They did this because of an income imbalance with their daily needs. The situation gets worse if the season and the weather do not allow fishermen to go fishing so that the debt to Retainer is getting bigger.

The poor fisherman family can still survive. It seems they do not feel the conditions of limitations experienced and even their daily behavior continues and lives life as usual. Besides, they don't even feel poor. Feeling not poor is led to the concepts of structural poverty and cultural poverty.

Several studies related to poverty of fishermen, including; Firth (1966) "Malay Fisherman", Sallatang (1982) on the Fishing Community that emphasizes the term "Punggawa-Sawi", a small group of sociological study, with a functional structural approach that found that in the Punggawa-Sawi group adaptation functions had taken place, achievement of goals, integration, and maintenance of patterns to create social harmony. Likewise with research conducted by 
Basuni (1981) on the view of fishermen who think that fishing is indeed a necessity and is fate for them; Nurland (1988) and Anriani, et al., (2018), regarding the role of women fishermen in a structurally functional household see the role and function of husband and wife in a fisherman's household.

Cahaya (2015), Wekke \& Cahaya (2015) found that the root causes of poverty among fishermen are a lack of ability to manage resources and time, as well as access to education that is not utilized. This is caused by cultural factors that fetter the fishermen.

Also, Siswono (2008) highlighted the poverty resistance of the fishermen. The study was about poverty in fishermen due to the lack of response to available jobs, so they could not develop as expected. This is also related to cultural aspects in the lives of fishermen.

This study focuses on the cultural aspect of religious appreciation in the form of fatalistic attitudes as the cause of fishermen poverty. Arifin et al., (2018) stated that fishermen in Indonesia stronghold the supra-rational aspects of their lives. This condition also occurs in the people in the Segeri Sub-district, Pangkajene Islands District, South Sulawesi Province, who have strongly implemented the rituals connected to the metaphysics (Halim et al., 2017). This study aims to explore and reveal the work process of religious appreciation that rise fatalistic attitudes that are the cause of poverty in the fishing community.

\section{Literature Review}

\section{A. Culture in Fishing Communities}

Culture is a value or habit that is owned by the community in carrying out actions in their lives. Culture means material or material and non-material aspects. Taylor (2010) argues that culture is a historical force that adversely affects the low productivity and social inequality in fishing communities is internal because it has long undermined our society, precisely at the beginning of the 17th century. The strength these are spiritual forces (Sufism) which have implications for poverty culture from a cultural perspective.

Cultural factors in economic development in Indonesia were firstly discussed by Boeke in his dissertation (1946). the study concluded that Indonesia's economic system in the past was static and pre-capitalist and impossible to turn into a dynamic and capitalist economic system because in the people's economic system orientation mysticism is stronger than the orientation of economic development. This static nature, according to Boeke, had caused people in Indonesia poor in the colonial era.

Geertz (1963) in his involuntary theory refutes Boeke's conclusion that the static nature of people in Indonesia causes being poor and colonized, it is colonized so that the static nature arises. During the colonial period, the Dutch did not encourage agrarian-industrial transformation, but crushed a dynamic economic system over a static economic system (the era of forced cultivation), so that population growth was absorbed inward, Indonesians became static and deterrent looked forward. In this phenomenon, Geertz calls it agricultural involution, a negative change from an agrarian-industrial transformation.

Geertz's statement about forced cultivation as a cause of Indonesian weakness was denied by Soewardi (1996: 280) with the fact that Indonesians had been weak since the mid-17th century. According to Soewardi, the weak nature is caused by the fact that Muslims entering Indonesia have lost their vital role. At first, the merchants were very dynamic, but because most were married to aristocratic daughters, their offspring were educated in royal traditions that prioritized character and abandoned trade, then combined with Hinduism which gave priority to nobility, eventually giving birth to a culture of nobility with instrumental values the weak. 


\section{B. Fishermen Poverty}

Poverty has various main dimensions, including; the material dimension is in the form of food shortages and employment that leads to hunger or lack of food. The next dimension is the psychological dimension, among others; powerless, voiceless, dependency, inferior feeling. On the access dimension, which is in the form of inability to access services/infrastructure, as well as the dimensions of assets or property, in the embodiment of not having assets as capital to conduct a decent life such as physical capital (land, livestock, work equipment, occupancy and so on).

Poverty is defined as a condition where a person is unable to maintain himself following the standard of life of the group and is also unable to utilize his mental or physical energy in the group. Historically, the rich and poor together side by side has not been a social problem. Social problems occur when trading develops very rapidly and the emergence of new social values. With the development of trade throughout the world and the establishment of a certain standard of living as a habit of society, poverty arises as a social problem. Poverty is considered a social problem if the difference in the economic position of the community members is determined explicitly (Soekanto, 1997).

According to Lewis (1960), poverty is a culture. The statement is a finding of his study in Latin American Communities both in rural and urban areas to understand their causes of poverty. This research also explains that poverty can arise as a result of cultural values shared by the poor themselves. This situation is rooted in poor environmental conditions and has been passed down from generation to generation. In other words, the poor have promoted the values and behavior of poverty for generations. This behavior resulted; people who live in a culture of poverty find it difficult to free themselves from their influence.

Cultural poverty refers to the problem of individual attitude or society caused by cultural factors, such as laziness, inefficiently life, passive, despite some efforts to solve their problems.

\section{Research Methodology}

This study is a qualitative study that reveals aspects of culture as a cause of poverty in fishing communities. There are two cultural aspects in this study namely; (1) instrumental value, and (2) fatalistic attitude. Data on this indicator was obtained through in-depth interviews from five traditional fishermen categorized as Sawi in Pandang -Pandang Village, Arungkeke District, Jeneponto Regency, South Sulawesi Province. To strengthen the interview data, observations were also made on the social life of the fishing community supported by related literature studies. The data collection was analyzed using the three path technique (Miles \& Huberman, 2000) such as data reduction, categorization, and concluding.

\section{Results and Discussion}

\section{A. Sustenance is God Determination}

Faith and hope in God is a tradition handed down from the fishing community of PandangPandang village. This belief is also strengthened and preserved in the form of rituals led by Pinati (The Elders). The Pinati share the belief that Life is God-Given. God has determined men`s fortune and men do not know the magnitude of the provisions of that provision. Men only seek and live, but all about sustenance is God's determination. A Pinati, KK (58 years old), who is also an informant stated:

"If God has determined sustenance for a certain man that he only has a glass of water so the man must work hard to catch it. The man cannot go beyond a glass of water. If 
he tried to go beyond that capacity, the water will spill to another man." (Interview on August 20, 2018)

Additionally, Sawi Papekang (crew of a fishing boat) believes the same thing that sustenance has been determined. They are indicated to be quickly satisfied when they have obtained fishing yield, so they prefer the work of Pagandeng Juku (fish retailer) to Papekang Lompo (fishing fishermen with their equipment). Although some of them, have an income, that is only enough to live daily, not for the long term.

According to Kluckhohn (in Koentjaraningrat, 1982), this is indicated as a cultural orientation, such as the resignation of the fishermen who accept the fate of having to bear the debt due to the fishing yield does not cover the production costs that have been calculated by the parachutes' (financiers and production equipment). In the view of fishermen, sustenance is the same as death. Whatever is done, whatever the outcome, it has been destiny. In general, the fishermen believe in the principle of "anjo nikanaya assele 'batuji ridalleka" meaning that the yield (catch) is very dependent on the sustenance (fate or fate of God) for them, dalle (sustenance) everyone has been determined (both quality and quantity) by the Almighty. This shows the systematic dependence of "worldly" life on sacred "religion", where the worldly has no value unless it is related to "religion". The dualistic work and fate where worldly work is not done are based on efficiency for productive work ethics. "God's approval" with sharia observance, on the one hand, works efficiently and the sustained fortune is interrelated but not causal.

For those who have the understanding "bahwa anjo nikanaya assele' batuji ridalleka" contains the meaning of hassele or dalle which refers to Erona Karaeng Allahu Taala ("merciful of God") which is abstract and mysterious. Fishermen believe that the number of fish caught is believed to be God's "Merciful of God" which is absolutely by His will so that what can be done is to pray and improve e sharia, not by enhancing professional skills in service.

In the end, the belief as above gives birth to the absolute dependence of all events on the "favor" of God in His destiny, which is free from all human actions, making ascetic piety not resting on the empirical world, but on that destiny. They strongly believe in that belief, even in the extreme a fisherman informant ( 49 years) expressly states:

"The tools or equipment, modern or traditional, it does not affect our yield." (Interview on August 24, 2018).

On the other hand, the "Merciful of God" is also supernatural and mysterious that cannot be recognized after the event. High enthusiasm for achieving economic achievement is believed not to be causally related to fate, fortune, and achievement unless seen as lacking trust in God's "favor". This understanding is seen in different levels of fishermen. But for other groups of fishermen, the more inconsistent with the Erona Kareng Allahu Taala or "God's favor", the more productive they look, even though they are seen and see themselves as less godly.

Looking for sustenance can be done in two ways, namely through the mind (supernatural) and the outward way (effort). For many fishermen, the inner (supernatural) method is more dominantly believed to be the only "best" way to find sustenance. This was seen at the salvation ceremony before each fish season in honor of the Khaidir Prophet Alaihissalam. The ceremony is a way to request that they survive in the sea and get the abundant fortune. They are convinced that the Khaidir Prophet Alaihissalam will appear with his white robe which is a sign of good luck. Although, it is not easy for fishermen watch it. 
They are familiar with the old tradition of belief (ancestors) that in the unseen world as in the real world, every place is inhabited (controlled) by spirits. They communicated with spirits traditionally through offerings and prayers from a Pinati. This tradition has lasted since preIslam until now. Likewise, fortune - fate - destiny is also seen from the unseen world because it comes from God. The unseen world is ruled by God's messenger. Therefore the question of a better livelihood (increased income, prosperity, and luck, etc.) must be pursued supernaturally, namely by respecting the resident (ruler) who was rescued. Therefore, in the Bugis community of Makassar, especially in rural areas contained "dualism of trust", on the one hand, believe in spirits as bearers of sustenance sourced from ancestral beliefs, on the other hand, because they have embraced Islam then they also believe in God Almighty as a provider of sustenance.

All results of operations are submitted to the Almighty. If they don't get profits or they catch less, they accept what they are. Because they believe that the sustenance obtained is determined by the Almighty. This causes a lack of motivation or ambition of fishermen to improve their economy and standard of living because they always feel sufficient in their lives. Although with the conditions of life as it is, but never feel worried about the situation.

Through the inner way, the fishing communities in the Pandang-Pandang village tend to be passive, so that instrumental values do not develop. They prioritize prayer in the form of rites and mystics rather than efforts to develop their instrumental values. Herein lies the relevance of what McClelland (1987: 48) states, cultures that have low Achievement Motives (nAch) may pay more attention to the preservation of their traditions, especially in religious settings.

\section{B. The Weakness of Instrumental Values}

Weak instrumental values for some fishermen informants were formed through a long historical process, sourced from the cosmological local doctrine which in its development became part of the local fishermen's knowledge system, including: (1) reliance on the absolute will of God carried out through the inculcation of surrender oneself to fate and destiny; (2) neglect of world affairs which is done through prioritizing the fulfillment of the Godhead orientation and "ignoring" worldly orientation and inculcation of attitude: zuhud (distance from world affairs), qanaah (limiting world love), uzlah (avoiding the crowd).

Poverty and social inequality in fishing communities are not only caused by the exploitation of financiers but also by cultural aspects that are not so visible. Related to this cultural aspect, it can be traced through the Punggawa-Sawi work relation system of parangka' and work conditions of the fishermen themselves.

In the parangka' system, the Punggawa guarantees all the needs of Sawi and his family. This situation is evident especially in the lean season which makes fishermen unable to go to sea. For the Sawi, this is a blessing because their needs are still being met for the Punggawa's dependents even though they are unemployed. Yet in this situation, other job opportunities must be sought and done to supplement income. Some work can be done such as masons or construction workers, and plantations. This happens because the cultural orientation that exists in him is only limited to work for a living. In another aspect, they believe in the fate that happens to them. An informant namely BHR (46 years) revealed the following:

"To live in this life, we must believe one thing; whatever we do, our lives never change because God has determined ours." (Interview on August 21, 2018)

This belief is embedded very strongly in their communities. The impact that occurs further due to dependence is the lack of fighting spirit and enthusiasm to work harder.

Copyright $($ 2019. Owned by Author(s), published by Society. This is an open access article under CC-BY-NC-SA License. 
Their beliefs are also contained in the principle of 'Sukkuruminne tawwa rinigappayya nasaba' niamo nikanre siagang punna la'busuki niaji parangka' ka assaretawwa angnginrang' which means that the income is limited to daily needs, after all, parangka', the fishermen leader, has guaranteed their needs. In the context of cultural orientation, this principle ends at the conclusion that fishermen work only for a living. If this is placed in the concept of cultural orientation, Kluckhohn (in Koentjaraningrat, 1982); then the orientation of such fishermen belongs to the fatalistic group. This is because they stop working after income is fulfilled. They work no more than that, even though they can do more than that, for example, to save money in preparation for the future.

On the other hand, during the fishing season, adequate catches obtained are not directed to the stability of the fulfillment of their basic needs but directed to the fulfillment of consumptive needs.

Observing the above description, we can see an indication of the weakness of instrumental value in the fishermen themselves as contained in a fatalistic cultural orientation, consumptive cultural orientation, and income levels that are full of uncertainties.

The phenomenon of poverty in the fishing community based on the results of this study places a fatalistic attitude in a central position in historical studies as a cause of the weak instrumental values of some fishing communities.

In the course of history, religious appreciation related to God, Man, and Nature as a cosmological system of local communities has formed cognitive assumptions about the basic problems in life that are a fatalist. This causes the instrumental values of adherents to not develop and eventually experience poverty which in this study is called cultural poverty. In South Sulawesi, cultural aspects have a distinctive style that may be different in other places, that is, they still believe in mystical things.

Cultural poverty for working fishermen in fishing communities is traced through traits commonly called a strong feeling of marginalities such as fatalism or resignation to fate, wastefulness, and dependency. It can be traced through the comprehension of five basic problems in life as stated by Kluckhohn (in Koentjaraningrat, 1982: 31) which includes; the nature of life, the nature of work, human perception of time, human views of nature, and the nature of human relationships with each other that determine the orientation of human cultural values.

At the research location, the origin of the fatalistic attitude is seen in the way of their comprehension or interpretation of various things. The appreciation of the nature of life is temporary, marked in work only for a living, more time orientation leads to the afterlife, and submissive to the awesome nature and a sense of dependence on others high enough so that there is no need to be too diligent in trying. Human cultural orientation like this is classified in the fatalistic group. In the Islamic psychology perspective, Jabariyyah adherents tend to be apathetic, and have weak instrumental value or are not motivated to excel.

Weak instrumental value is then exacerbated through exploitative work relations by capital owners towards working fishermen, both of which are functionally related in the social structure of the fishing community as their container as a cause of poverty (Hakim, 2016). This exploitation was also strengthened by research by Arifin (2015) and Agustang (2006) in the form of unfair distribution of fishermen's catches that benefited the owners of capital rather than working fishermen.

The results of historical studies show the relevance of empirical evidence through the study of several cases to see the influence of exploitative capitalism. Through the power of capital 
owners, with the main doctrine of maximizing profits, has formed an exploitative attitude for capital owners towards working fishermen and also towards marine fisheries resources.

\section{Conclusion}

Fatalistic or an Islamic term known as 'Jabariyyah', is a cultural value as the result of their appreciation of God, the nature of life, and the nature of human beings. Fatalism is one of the trust values which is a cause of poverty in the fishing communities in South Sulawesi Province, Indonesia.

Fatalism as a result of appreciation (thoughts and experiences) is a dialectical process that lasts a long time in the community. The indicators are the appreciation of God, appreciation of man, appreciation of nature, and appreciation of life. The result of this appreciation is to accept that sustenance is God's determination and men only live and accept it as well. As in a saying "men only seek and live, but all about sustenance is God's determination". This belief is what manifested in the social actions of fishermen. The manifestation leads them not to overworking to improve their situation and condition.

\section{Acknowledgement}

The author wants to appreciate to all people involved in this study. Special thanks to 1) Yapti Jeneponto, School of Economics; 2) Officers of Jeneponto Regency, South Sulawesi, Indonesia; and 3) Fishermen in Pandang-pandang village for making this study a success.

\section{References}

Agustang, A. (2006). Defleksi Sosio-Kultural Masyarakat Maritim Ke Arah Kepentingan Pembangunan (Studi Kasus Pada Komunitas Nelayan di Kabupaten Selayar Provinsi Sulawesi Selatan). Disertasi. Program Pascasarjana Universitas Padjajaran. Bandung. Anriani, H. B. (2018). Pengelolaan Sumber Daya Laut Nelayan Lokal. Kebumen: Pena Indis.

Anriani, H. B., Halim, H., Zainuddin, R., Wekke, I. S., \& Abdullah, A. (2018, May). Fisherman's Wife Role in Extending Household Income in Palu Gulf. In IOP Conference Series: Earth and Environmental Science (Vol. 156, No. 1, p. 012001). IOP Publishing.

Arifin, A., Anriani, H. B., \& Halim, H. (2018). Immanent and Transcendental Belief of Fisherman Community. Anthropologist, 33(1-3), 16-26.

Arifin, A. (2015). Kekerasan Struktural Dalam Relasi Kerja Pinggawa-Sawi. Jakarta: Orbit Press.

Basuni, F. (1981). Tidak Ada Pilihan Lain: Studi tentang Pandangan Nelayan terhadap Kerja di Pulau Balang Lompo Kabupaten Pangkep. Ujung Pandang: PLPHS Universitas Hasanuddin. Boeke, J. H. (1946). Oosterse Ekonomic. Den Haag: Nine Service.

Budi, S. (2008). Kemiskinan dan Perlawanan Kaum Nelayan. Jakarta: Laksbang Mediatama.

Cahaya, A. (2015). Fishermen Community In The Coastal Area: A Note From Indonesian Poor Family. Procedia Economics and Finance, 26, 29-33.

Firth, R. (1966). Malay Fishermen: Their Peasant Economy. London: Routledge and Kegan Paul.

Geertz, C. (1963). Involusi Pertanian: Proses Perubahan Ekologi di Indonesia. Jakarta: Yayasan Obor Indonesia.

Hakim, M. (2016). Persetubuhan Kapitalisme dan Struktur Sosial Pada Masyarakat Nelayan. Kebumen: Pena Indis.

Harifuddin, H., \& Zainuddin, R. (2017). Flood Disaster, Local Belief And Islam-sufism. El Harakah, 19(1), 41-52.

Imron, M. (eds). (2001). Pemberdayaan Masyarakat Nelayan. Yogyakarta: Media Pressindo. 
Kamaruddin, S. A., \& Halim, H. (2014). Mobilitas Pendidikan Nelayan di Kabupaten Sinjai. Indonesian Journal of Sociological Discourse (IJSD), 1(1): 56-67.

Kluckhohn, C. (1951). Value and Value Orientations in The Theory of Action. An Exploration in definition and clarification in Parson \& Edward Shils (eds). Toward a General Theory of Action. Harvard University Press.

Koentjaraningrat, K. (1982). Kebudayaan, Mentalitas, dan Pembangunan. Jakarta: Gramedia.

Kusnadi, K. (2002). Konflik Sosial Nelayan: Kemiskinan dan Perebutan Sumberdaya Perikanan. Yogyakarta: Lembaga Kajian Islam dan Sosial.

Kusnadi, K. (2004). Polemik Kemiskinan Nelayan. Bantul: Pondok Edukasi \& Pokja Pembaruan.

Lewis, O. (1960). Kisah Lima Keluarga: Telaah-telaah kasus orang Meksiko Dalam Budaya Kemiskinan. Jakarta: Penerbit Yayasan Obor Indonesia.

Masyhuri, M. (1999), Ekonomi Nelayan dan Kemiskinan Struktural. In Masyhuri (eds): Pemberdayaan Nelayan Tertinggal dalam Mengatasi Krisis Ekonomi: Telaahan terhadap sebuah Pendekatan. Jakarta: Pusat Penelitian dan Pengembangan Ekonomi dan Pembangunan Lembaga Ilmu Pengetahuan Indonesia.

McClelland, D. C. (1987). Memacu Masyarakat Berprestasi. Alih Bahasa Siswo Suyanto. Jakarta: Intermedia.

Miles, M. B., \& Huberman, M. A. (2000). Analisis Data Kualitatif. Jakarta: Universitas Indonesia Press.

Mubyarto, et al., (1984), Nelayan dan Kemiskinan: Studi Ekonomi Antropology di Desa Pantai. Jakarta: Rajawali.

Nurland, F. (1988). “Peranan Wanita Nelayan dalam Keluarga dan Rumah Tangga di Masyarakat Pantai Lappa Sinjai Utara". In Mukhlis (eds), Dimensi Sosial Kawasan Pantai. Ujung Pandang: P3MP Universitas Hasanuddin.

Rasool, M. S. A., Harun, M. F. M., Salleh, A. M., \& Idris, N. (2011). Poverty Measurement in Malaysia: A Survey of the Literature. Akademika, 81(1), 73-81.

Sallatang, A. (1982). Punggawa-Sawi: Suatu Studi Sosiologi Kelompok Kecil. Jakarta: Penerbit P \& K. Soekanto, S. (1997). Pengantar Sosiologi. Jakarta: RajaGrafindo Persada.

Soewardi, H. (1996). Filsafat Koperasi atau Cooperativism. Bandung: IKOPIN.

Suyanto, B. (2013). Anatomi Kemiskinan dan Strategi Penanganannya. Malang: In-Trans Publishing. Taylor, E. B. (2010). Primitive Culture: Researches Into the Development of Mythology, Philosophy, Religion, Art, and Custom. Cambridge University Press.

Wekke, I. S., \& Cahaya, A. (2015). Fishermen Poverty and survival strategy: Research on poor households in bone Indonesia. Procedia Economics and Finance, 26, 7-11.

Winahyu, R., \& Santiasih, S. (1993). Pengembangan Desa Pantai. In Mubyarto et al., Dua Puluh Tahun Penelitian Pedesaan. Yogyakarta: Aditya media.

\section{About the Author}

Maksud Hakim, completed his Ph.D. in Sociology from State University of Makassar, South Sulawesi, Indonesia, in 2011. The author is an Assistant Professor in the Department of Economic Development, Yapti Jeneponto School of Economics, Jeneponto, South Sulawesi, Indonesia. 